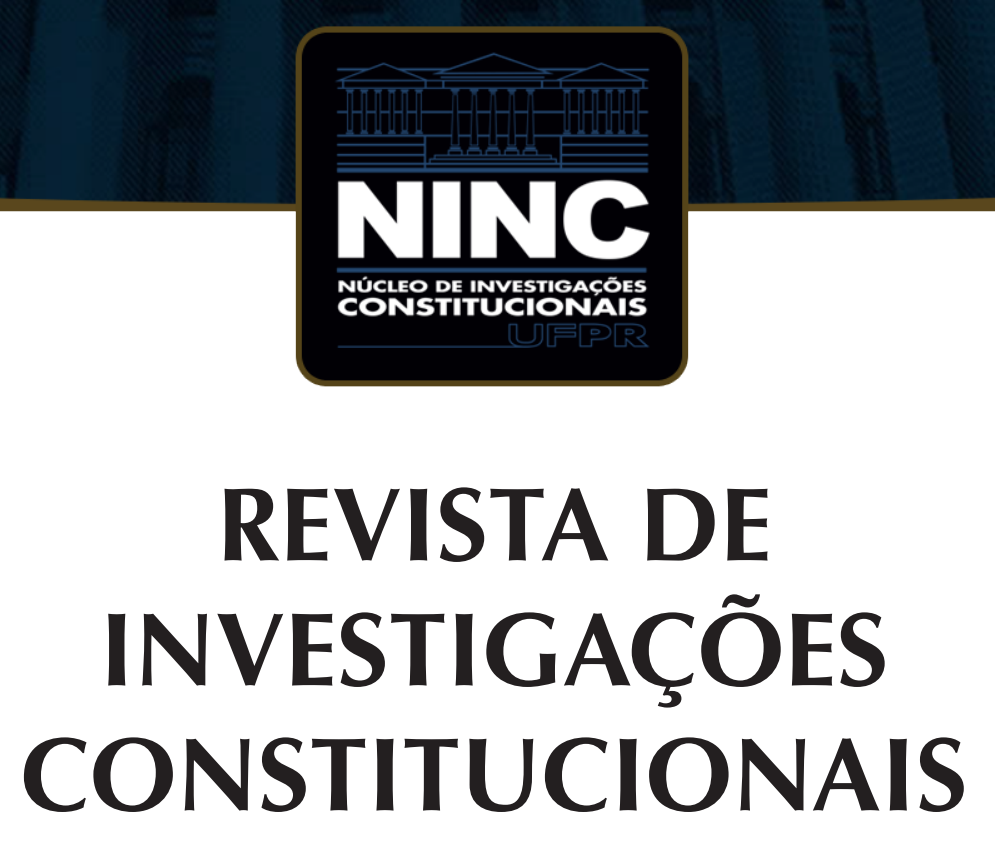

JOURNAL OF CONSTITUTIONAL RESEARCH

vol. 7 | n. 2 | maio/agosto 2020 | ISSN 2359-5639 | Periodicidade quadrimestral Curitiba | Núcleo de Investigações Constitucionais da UFPR | www.ninc.com.br 


\title{
Social media, disinformation, and regulation of the electoral process: a study based on 2018 Brazilian election experience*
}

\section{Redes sociais, desinformação e regulação do processo eleitoral: um estudo baseado na experiência eleitoral brasileira de 2018}

\author{
GUSTAVO FERREIRA SANTOS ${ }^{1, * *}$ \\ ' Universidade Católica de Pernambuco (Recife, Pernambuco, Brasil) \\ gustavo.santos@unicap.br \\ https://orcid.org/0000-0002-3790-3604 \\ Recebido/Received: : 02.01.2020 / January $2^{\text {nd }}, 2020$ \\ Aprovado/Approved: $17.10 .2020 /$ October $17^{\text {th }}, 2020$
}

\section{Abstract}

There is global concern about the impact that 'fake news' has on democratic decision-making processes. Democratic decision-making needs to be well informed and voters need a minimum of confidence in the information they receive about competitors. The Internet has increased the availability of information, but has allowed new ways of manipulating it to emerge. In recent electoral experiences, social media has increased the impact of misinformation on democracy. These experiences have shown us that Internet governance during the election campaign is an urgent issue. A laissez-faire approach to the electoral process is a threat to democracy because it allows all kinds of cheating. Institutions responsible for ensuring the integrity of elections need to try democratic resources to constrain competitors to behave responsibly. It is important to know the concrete experience of
Resumo

Existe uma preocupação mundial com o impacto que as "fake news" têm nos processos democráticos de tomada de decisão. A decisão democrática precisa ser bem informada e os eleitores precisam de um mínimo de confiança em relação às informações que recebem sobre os concorrentes. $A$ internet aumentou a disponibilidade de informações, mas permitiu o surgimento de novas maneiras de manipulá-las. Nas recentes experiências eleitorais, as mídias sociais aumentaram o impacto da desinformação na democracia. Essas experiências nos mostraram que a governança da Internet durante a campanha eleitoral é uma questão urgente. Uma abordagem de laissez-faire no processo eleitoral é uma ameaça à democracia porque permite todos os tipos de trapaça. As instituições responsáveis por garantir a integridade das eleições precisam tentar recursos democráticos para constranger os concorrentes a adotarem um

Como citar esse artigo/How to cite this article: SANTOS, Gustavo Ferreira. Social media, disinformation, and regulation of the electoral process: a study based on 2018 Brazilian election experience. Revista de Investigações Constitucionais, Curitiba, vol. 7, n. 2, p. 429-449, maio/ago. 2020. DOI: 10.5380/rinc.v7i2.71057

"This study was financed in part by the Coordenação de Aperfeiçoamento de Pessoal de Nível Superior - Brasil (CAPES) - Finance Code 001

" Professor de Direito Constitucional da Universidade Católica de Pernambuco e do Programa de Pós-Graduação em Direito da mesma universidade (Recife-PE, Brasil). Doutor em Direito pela Universidade Federal de Pernambuco. Mestre em Direito pela Universidade Federal de Santa Catarina. E-mail: gustavo.santos@unicap.br. 
a country that has suffered the attack of disinformation campaigns during an election period, studying the action of the body responsible for organizing this process. This article discusses the guarantee of the electoral process based on the case study of the 2018 Brazilian election.

Keywords: social media; internet governance; media regulation; democracy; electoral process. comportamento responsável. É importante conhecer a experiência concreta de um país que sofreu o ataque de campanhas de desinformação em período eleitoral, estudando a ação do órgão responsável pela organização desse processo. Este artigo discute a garantia do processo eleitoral com base no estudo de caso da eleição brasileira de 2018.

Palavras-chave: redes sociais; governança da internet; regulamentação dos meios de comunicação; democracia; processo eleitoral.

\section{CONTENTS}

1. Introduction; 2. Data collection and analysis and other methodological issues; 3 . The specificity of the electoral period in a constitutional democracy; 4. Brazilian model of organization of the electoral process; 5. The presidential elections of 2018 and disinformation; 6 . The Brazilian Electoral Justice and the "fight" against disinformation in social media; 6.1. Higher Electoral Court deciding lawsuits by political parties and candidates over disinformation; 6.2. Higher Electoral Court supervising the electoral process; 7 . What lessons can we draw from the experience? $\mathbf{8}$. Conclusions; 9 . References.

\section{INTRODUCTION}

Globally, democracies are being impacted by intentional processes of dissemination of false information over the Internet. This happens concomitantly with a process of declining democratic beliefs and growing authoritarian discourse. Misinformation campaigns weaken institutions and fuel this process of democratic decay.

The lie has always been present in politics. However, the reach and speed of the Internet have increased concerns about it. An occasional problem, which affected institutions only in specific places and opportunities, became a structural threat to democracy itself. While eroding confidence in institutions such as parliament, parties, and the media, misinformation campaigns also deepen ideological divisions, polarize and radicalize societies.

Misinformation campaigns are not only a problem for democratic institutions, but also reach businesses, churches and other institutions as well as individuals. $\mathrm{Ne}$ vertheless, there are specificities in the democratic process that require urgent solutions, and election periods should be observed more closely. Reliable information is a fundamental resource for democracy. In a democracy, the period of the electoral campaign requires special attention focused on protecting the conditions of the debate. False information spreads very quickly and can be decisive for voter choice. This campaign time limitation requires more effective tools to avoid or minimize the impacts of misinformation.

Currently, electoral processes are impacted by the use of an enormous amount of data on the Internet. Big data is an essential tool for political marketing strategies 
and actions. It is legitimate for the participants in the electoral debate as parties and candidates to know the profile of voters in order to enhance the quality of the speeches that are addressed to them. However, it is dangerous that knowledge of voters' wishes and behaviors be used to manipulate debates, especially when trolls and robots ${ }^{1}$ are used. When there is massive misuse of information, the integrity of elections is tainted. The conviction of voters is formed by a dirty process in which false information plays a central role. In addition to the erosion of the image of the candidate affected by the disinformation campaigns, these devices change the focus of the political debate, leaving aside important issues that should be central. Much time and energy has been wasted in trying to respond to disinformation campaigns and reestablish the truth. All of this damages the quality of the decision-making process.

Governments and society still do not have satisfactory answers to this problem. We are still at the first approach to the issue, trying to understand the scope of the attack. There will be no easy answer to the problem, especially for us law researchers. There are numerous variables that we need to take into account. For better reflection on the issue, an analysis of real experiences can bring knowledge and help shape solutions. Among the most recent national experiences, we believe that the study of the 2018 Brazilian electoral process could clarify a whole range of issues involved in the issue. It was a process strongly impacted by the dissemination of false news. When the Brazilian elections of 2018 took place, it was not possible to say that it would be a surprise to witness the misuse of the Internet in the democratic debate. There had already been some bad experiences shortly before, such as Brexit, the Trump election and the cancelled elections in Kenya. Institutions responsible for maintaining the integrity of the electoral process were already reasonably aware of the threat posed by the spreading of false information on the Internet.

As was to be expected, the election debate was flooded with false news. The disinformation has happened in all social media. However, WhatsApp groups were essential for spreading lies, mainly because of the difficulty of monitoring. At that time, attention was focused mainly on Facebook and Twitter because of experiences from other countries, where these social networks had been central to campaigns of disinformation.

In this paper, I want to discuss the struggle of democratic institutions due to disinformation using analysis of the posture assumed by the higher electoral court-TSE regarding the problem of disinformation campaigns. This institution is central in the

\footnotetext{
This problem was particularly noted in the debates before the referendums of Brexit and Catalonia. Read more in BOOTH, Robert et al. Russia used hundreds of fake accounts to tweet about Brexit, data shows. The Guardian, November 14, 2017. World. Available at: <https://www.theguardian.com/world/2017/nov/14/how-400-russia-run-fake-accounts-posted-bogus-brexit-tweets>. Retrieved Feb. 9, 2019. And PALMER, Ellis. 'Spain Catalonia: Did Russian 'fake news' stir things up?. BBC, November 18, 2017. Europe. Available at: <https://www. bbc.com/news/world-europe-41981539>. Retrieved May 17, 2019.
} 
electoral process because it is responsible for organizing national elections and resolving disputes over the application of electoral legislation. While we study their performance, we try to discuss the limitations that institutions face in the battle against "fake news" and the possibilities that are presented in this topic.

\section{DATA COLLECTION AND ANALYSIS AND OTHER METHODOLO- GICAL ISSUES}

Fake news is "fabricated in-formation that mimics news media content in form but not in organizational process or intent".2 The term "fake news" is commonly used to emphasize that the information conveyed is not correct. Despite its distant historical roots, the term was popularized during the United States elections in 2016, having been chosen as "word of the year" in 2016 by the Oxford Dictionary and in 2017 by the Collins Dictionary. Donald Trump politicized the expression, using it to discredit any news that harmed him. ${ }^{3}$

It does not seem to us the best term to designate the phenomenon, especially in its imprecision. The phenomenon is more complex. In this research, we prefer to avoid the term "fake news" and we use disinformation or misinformation. This choice takes into account the typology proposed by Wardle and Derakhshan ${ }^{4}$ which divides the phenomenon of communication disorder into three types:

Dis-information. Information that is false and deliberately created to harm a person, social group, organization, or country.

Mis-information. Information that is false, but not created with the intention of causing harm.

Mal-information. Information that is based on reality, used to inflict harm on a person, organization, or country.

We believe that studying the behavior of the authority responsible for regulating the electoral process could shed light on the problem of combating disinformation. To design the study, we realized that it is necessary to analyze the court's performance on

\footnotetext{
2 LAZER, David M. J et al. The Science of Fake News. Science, [s.I.]. v.359, issue 6380, p. 1094-1096, March 09, 2018. Available at: <http://science.sciencemag.org/content/359/6380/1094>. Retrieved May 29, 2019.

3 KALSNES, Bente. Fake News. Oxford Research Encyclopedia of Communication. September 2018, Available at: <https://oxfordre.com/communication/view/10.1093/acrefore/9780190228613.001.0001/acrefore-9780190228613-e-809>. Retrieved May 27, 2019.

4 WARDLE, Claire; DERAKHSHAN, Hossein. Toward an interdisciplinary framework for research and policymaking. Strasbourg: Council of Europe, 2017. Available at: <https://rm.coe.int/information-disorder-toward-an-interdisciplinary-framework-for-researc/168076277c>. Retrieved July 3, 2019.
} 
two different fronts: judging individual cases and exercising police power in the electoral process.

The information considered in this work was mainly obtained through direct consultations with the Court via email. Firstly, we were looking for information in the mainstream media about the role of electoral justice on the issue, and we were searching for processes that involved the subject in the court database on their website. In the newspapers, there was plenty of news, especially on dates before the election, about the existence of a commission set up specially to advise the court on fake news.

On January 22, 2019, we sent an e-mail to the Higher Electoral Court President's office asking whether there was a report of a special commission that advised the court about "fake news". In the response, the Court stated there was no report and indicated two news stories on the subject on its website.

Regarding the research on processes presented for or against candidates, there was a difficulty delimitating the indexing terms. Some keywords, like "lie", for example, lead to an overly broad outcome, displaying processes that have nothing to do with campaigns of disinformation. Other keywords, like "fake news", for example, leave out some processes that deal with disinformation.

By the time we were searching with a few different keywords, we had found information that interested us. It was published on the Higher Electoral Court's home page news about its work against disinformation saying that it acted swiftly in trial proceedings on fake news during Elections 2018. The source of that information was a data collection by a court itself. There was information about the time in which the processes were decided. One more time, we sent an e-mail asking for this survey. They did not send us the study, but they sent the list of processes that were considered in the study. Although we were not directly interested in the speed of the process decision, we adopted the list of prosecutions for the research, since it was an official manifestation of the court.

The small availability of detailed information about the work done by the court limited our study. The exchange of emails between myself and the President's Office shows a lack of transparency. In the first email, we asked, "How many Council meetings occurred and on what dates?"We also asked about the results of the three attributions in the act that created it: a) what research on electoral rules the council undertook, (b) what matters were submitted to the Council by the Presidency of the Court, and (c) what actions and goals were proposed that aimed to improve norms? They answered, saying that the minute meetings were secret. We replied, showing disagreement. We said that it was a piece of information with a public interest. Then they accepted part of my request, and they said the number of meetings, but they reinforced that minutes of the meeting were secret. 


\section{THE SPECIFICITY OF THE ELECTORAL PERIOD IN A CONSTITU- TIONAL DEMOCRACY}

The elections are a key moment in democratic life. When deliberate disinformation campaigns decide elections, we are faced with a problem of the integrity of the electoral system. Electoral malpractice undermines the legitimacy of elections. ${ }^{5}$

Finding an appropriate solution to the problem of disinformation and misinformation in election campaigns is today the greatest challenge for constitutional democracies. We cannot disregard the fact that the world is experiencing a wave of weakening democracy concomitantly with the growth in the use of 'fake news' on the Internet during election periods. In the annual research conducted by Freedom House, between the years 2005 and 2018 there was a clear process of decline of political rights and civil liberties. ${ }^{6}$ Freedom House itself recognizes that the Internet plays a key role in this process. ${ }^{?}$

The fight against disinformation campaigns in a constitutional democracy is difficult because it is subject to the limits that are proper to this type of political-constitutional model. While in an autocratic state all means are available to the ruler, in a constitutional democracy the government is not free to take all measures it deems necessary. A constitutional democracy has a set of restrictions on the use of state power because the protection of the rights of individuals and groups is at the core of its concept. Among the most important limits are the basic rights that protect human communication. The Brazilian Constitution includes freedom of speech in its bill of rights and provides a set of guarantees for the communication process.

In the electoral process, a paradox can be noted: while it is important to protect as many speeches as possible, manipulations that make the choice process flawed must be prevented. This is a limited period of time, which can maximize the damage of a massive disinformation campaign. The short time of an election campaign makes difficult for the responsible authorities to ensure the integrity of the process, as there are risks both in its omissive stance and in a disproportionate action.

The balance in the solution to be found is difficult, but it is essential. In this search for a solution, the electoral process needs to be understood in its specificity. There is a general justification for a stronger regulation of speeches to prevent the formation of opinion from being manipulated. That is how in many countries election advertising

\footnotetext{
NORRIS, Pippa; GRÖMPING, Max. Electoral Integrity Worldwide. Sydney: The Electoral Integrity Project, 2019.

6 FREEDOM HOUSE. Freedom in the World 2019. Available at: <https://freedomhouse.org/sites/default/ files/Feb2019_FH_FITW_2019_Report_ForWeb-compressed.pdf >. Retrieved July 19, 2019.

7 FREEDOM HOUSE. Freedom on the Net 2019. Available at <https://www.freedomonthenet.org/sites/default/files/2019-11/11042019_Report_FH_FOTN_2019_final_Public_Download.pdf >. Retrieved Sep. 20, 2019.
} 
is done under very restrictive rules. However, these restrictions need to be strongly justified.

\section{BRAZILIAN MODEL OF ORGANIZATION OF THE ELECTORAL PROCESS}

In Brazil, the organization of the electoral process is under the responsibility of a branch of the judiciary. There is a professional structure exclusively for the elections, which operates permanently, although there are only regular elections every two years. (The terms are four years, but every two years we have municipal or national/regional elections alternately.) Nevertheless, there are no judges exclusively for functions in electoral law. The functions of "electoral judges" are exercised temporarily by state judges or federal judges appointed by the courts. In this structure, there is an electoral court for each state of the federation that organizes the regional and local elections, and there is a higher court in Brasilia that organizes the national elections.

The advertising for electoral purposes is subject to a set of constraints. The law dictates which media candidates can use and how they can use it. For example, candidates and parties cannot pay for time on the radio and television for advertising. The time is divided among the candidates, following rules that consider the size of the party in Parliament. There are also restrictions on social media advertising. Flyers and billboards must identify the party or coalition, the company that made the material and the number of prints.

During the electoral period, there are judges specifically appointed to oversee election advertisements and decide on lawsuits where someone alleges that there has been a breach of boundaries.

At the end of the electoral process, the courts declare the legality of the process and issue declarations that allow elected officials to take office. At this time, or later, in a lawsuit for this purpose, it is possible to recognize the nullity of the process.

For this research, it is required to note that electoral law-after defining other forms of nullity-declares the power to nullify elections in case of fraud:

Art. 222. Voting can be nullified when distorted by falsehood, fraud, coercion, use of means referred to in art. 237 (abuse of economic power or power of government), or use of propaganda process or capture of votes prohibited by law (Electoral Code) ${ }^{8}$

Once the court has declared the nullity of the majority of votes, canceled the registration of the winning candidate or canceled the entire process, new elections should take place. There have already been several cases in municipal or state elections.

8 BRAZIL. Código Eleitoral, Lei n. 4.737. Diário Oficial da União, July 15, 1965. Available at: <http://www. planalto.gov.br/ccivil_03/leis/l4737.html>. Retrieved July 7, 2019. 
However, this is unlikely to be used in national elections because of the high cost of doing so.

In 2009, electoral legislation was amended to include specific rules on electoral advertising on the internet. The law says that advertising is allowed but makes a set of restrictions, requiring, for example, clear identification of who engaged in a content push. ${ }^{9}$ A Resolution of the TSE states that elections activities disseminated on the Internet should be carried out with the least possible interference in the democratic debate. $^{10}$

\section{THE PRESIDENTIAL ELECTIONS OF 2018 AND DISINFORMA- TION}

The 2018 Brazilian presidential elections happened amid a growing process of polarization between right and left political currents. Since the massive street protests that took place in 2013, this radicalization of political dissent has accelerated. The impeachment of President Dilma and the arrest of former President Lula contributed to this polarization trend. This growth was shown by a study of political views on Facebook that found: "between 2014 and 2016, political differences hardened into polarization. We saw users who once comprised six visibly distinct communities of interest separate into just two groups with very little overlap: progressives and conservatives".11

Social media are environments that promote polarization and disinformation: "Homogeneous social networks, in turn, reduce tolerance for alternative views, amplify attitudinal polarization, boost the likelihood of accepting ideologically compatible news, and increase closure to new information. Dislike of the 'other side' (affective polarization) has also risen. These trends have created a context in which fake news can attract a mass audience."12

In this toxic environment, disinformation campaigns strongly affected the Brazilian 2018 elections. WhatsApp was the primary means of spreading false information for political purposes. The application is top-rated in Brazil because SMS was costly in the country. Before the arrival of WhatsApp, SMS services cost 55 times more than it did in the United States. In addition to being a free app, phone companies could offer packages of data allowing WhatsApp to be used indefinitely. Moreover, WhatsApp allows

9 BRAZIL. Lei n. 9.504. Diário Oficial da União, September 30, 1997. Available at: <http://www.planalto.gov. br/ccivil_03/LEIS/L9504.html>. Retrieved July 7, 2019.

10 TSE. Resolution n. 23,551 / 2017. Available at: <http://www.tse.jus.br/legislacao-tse/res/2017/ RES235512017.html>. Retrieved July 7, 2019.

11 ORTELLADO, Pablo; RIBEIRO, Márcio Moretto. Mapping Brazil's political polarization online. The conversation, August 3, 2018. Politics/Election '20. Available at: <https://theconversation.com/mapping-brazils-political-polarization-online-96434>. Retrieved May 7, 2019.

12 LAZER, David M. J et al. The Science of Fake News. Science, [s.l.]., v.359, issue 6380, p. 1094-1096, March 09, 2018. Available at: <http://science.sciencemag.org/content/359/6380/1094>. Retrieved May 29, 2019. 
the creation of groups. More than ninety percent of mobile phones have the app; it has become essential to individuals and businesses alike. ${ }^{13}$

A delegation from the Organization of American States (OAS) that observed the elections in Brazil pointed out disinformation. In a report on the visit, committee members demonstrated a positive view of the election period, praising the voting system. Notwithstanding the positive report, they highlighted the problem of disinformation and its complexity at that moment: "although the phenomenon had been visible in electoral processes in other countries, Brazil's elections presented new challenges, such as the use of encrypted systems for mass diffusion of disinformation."14

An episode shows the size of the problem in the 2018 elections. In the second round of elections, Haddad's campaign team created a channel for people to send fake news spreading allegations. This channel consisted of a website and a telephone number for sending messages by WhatsApp. According to information from their party's website, in the first twelve hours, they received more than 5,000 complaints.

It was clear that this was not an innocent distribution of false information. The size of the disinformation campaigns indicated that there was some considerable structure behind it.

The newspaper Folha de São Paulo ${ }^{15}$ denounced, at the time of the election campaign, the illegal practice of sending messages by WhatsApp, which was paid by Bolsonaro's supporters. Entrepreneurs who supported Bolsonaro paid for marketing agencies to bombard WhatsApp users with disinformation and misinformation about the Workers party and Fernando Haddad. This conduct implies irregular electoral funding.

According to the newspaper, the marketing companies were getting phone numbers that were often provided illegally by debt collection companies or by phone company employees. With these numbers, they created WhatsApp groups segmented by region, gender, age, or income and sent messages. Also, according to the newspaper, companies were paying for these services, which were characterized as illegal election donations. These companies would have spent more than $\mathrm{R} \$ 12,000,000$, which is about $\$ 3,000,000$.

One of the most widespread pieces of disinformation in the campaign was that Haddad had distributed a "gay kit" to schools when he was Minister of Education. In the

\footnotetext{
13 SABOIA, Fernanda. The Rise of WhatsApp in Brazil Is About More than Just Messaging. Harvard Business Review, April 15, 2016. Available at: <https://hbr.org/2016/04/the-rise-of-whatsapp-in-brazil-is-about-more-than-just-messaging >. Retrieved May 7, 2019.

14 ORGANIZATION OF AMERICAN STATES (OAS). Preliminary EOM report, Electoral Observation Mission of the Organization of American States, 2018. Available at: <http://www.oas.org/documents/eng/press/Preliminary-Report-EOM-Brasil-2nd-round-ENG.pdf >. Retrieved July 17, 2019.

15 MELLO, Patricia Campos. Empresários bancam campanha contra o PT pelo WhatsApp. Folha de S. Paulo, October 18, 2018. Poder. Available at: <https://www1.folha.uol.com.br/poder/2018/10/empresarios-bancam-campanha-contra-o-pt-pelo-whatsapp.shtml>. Retrieved July 25, 2019.
} 
false narrative, this "kit" would have books and texts on homosexuality, and the Ministry would distribute them to six-year-olds. In a conservative country, where the evangelical public represents a quarter of the population, the false story spread rapidly. This story was not entirely invented. The news misrepresented the fact that a study had been done by the Ministry of Education to create educational material against homophobia to distribute among teachers. In the falsified version, they said that the kit included a Portuguese version of the book "Le guide du zizi sexuel" by the French writer Helene Bruller. ${ }^{16}$

A survey by "Ideia Big Data" for the Avaaz organization showed that $85 \%$ of Bolsonaro voters had contact with the false "gay kit" news. $56 \%$ of those who saw the story said they believed it. ${ }^{17}$ Of course, this does not mean that the false news decided their vote, especially since surveys point out that the consumption of misleading stories is higher in groups that already receive information with partisan biases, but this alerts us that the circulation and acceptance of lies were high during the election period.

Despite requests from academics and politicians, the company did not make any changes to the app that would reduce the negative impact on the election. Ten days before the second round, Cristina Tardáguila, Fabrício Benevenuto, and Pablo Ortellado ${ }^{18}$ (director of Agência Lupa, a fact-checking platform, computer science professor at the Federal University of Minas Gerais and public policy professor at the University of São Paulo, respectively) published an article in The New York Times asking WhatsApp to make the following changes on the platform before the election:

WhatsApp should undertake three measures immediately:

Restrict forwards. This year, after the dissemination of rumors on WhatsApp provoked lynchings in India, the company put restrictions on the number of times that a message could be forwarded. Globally, the number of forwards was reduced to 20, while in India it was reduced to five. WhatsApp should adopt the same measure in Brazil to limit the reach of disinformation.

Restrict broadcasts. WhatsApp allows every user to send a single message to up to 256 contacts at once. This means that a small, coordinated group can easily conduct a

\footnotetext{
16 LONG, Clara. How False News Haunted the Brazilian Elections. Slate, October 30, 2018. Technology. Available at: <https://slate.com/technology/2018/10/brazil-election-fake-news-whatsapp-facebook.html>. Retrieved May 21, 2019.

17 IDEIA BIG DATA. Elections and Fake News. October 2018. Available at: <https://avaazimages.avaaz.org/ EN\%20IDEIA\%20-\%20Report\%20AVAAZ_v2\%203_EN\%20version_pdf\%20\%281\%29.pdf>. Retrieved May 17, 2019.

18 TARDÁGUILA, Cristina; BENEVENUTO, Fabrício; ORTELLADO, Pablo. Fake News Is Poisoning Brazilian Politics. WhatsApp Can Stop It. The New York Times, October 17, 2018. Opinion. Available at: <https://www.nytimes. com/2018/10/17/opinion/brazil-election-fake-news-whatsapp.html>. Retrieved May 18, 2019.
} 
large-scale disinformation campaign. This could be prevented by limiting the number of contacts to whom a user could broadcast a message.

Limit the size of new groups. New chat groups created in Brazil during the next two weeks should have a limit on the number of users. This wouldn't affect existing groups.

The authors contacted WhatsApp and presented the suggestions, but the company answered that there was not enough time to do the changes. They disagreed and cited as evidence that that possibly was the case of India, ${ }^{19}$ where the company did make changes to combat a wave of violence that was spreading by WhatsApp, as there were at least 30 lynchings after the fake news spread on the platform.

Fact-checking agencies did the most effective work against disinformation. Several initiatives took place during the electoral period. One of these agencies was explicitly created for this period, in an initiative funded by Google and Facebook, which involved 24 different media, the so-called "Projeto Comprova" (Project Proves). ${ }^{20}$ However, there were limitations, mainly because the work of information checking agencies focused on visible content, i.e., material that was posted on social networks, such as Twitter or Facebook, and information received in complaints sent by people who had contact with the false information from WhatsApp.

\section{THE BRAZILIAN ELECTORAL JUSTICE AND THE "FIGHT" AGAINST DISINFORMATION IN SOCIAL MEDIA}

\subsection{Higher Electoral Court deciding lawsuits by political parties and candidates over disinformation}

According to official information from the Supreme Electoral Court, 50 lawsuits involved allegations of fake news. Of these sets of cases, sixteen had favorable preliminary injunctions by the court that ruled that contents were taken from the Internet or TV.

Only three of the 50 cases concerned radio and television during election time. The other court cases concerning issues of disinformation were in social media. This prevalence of lawsuits on disinformation in social media can be explained by the difference between these media, radio and television. In the case of broadcast, the electoral

\footnotetext{
19 HERN, Alex; SAFI, Michael. WhatsApp puts limit on message forwarding to fight fake news. The Guardian, January 21, 2019. Technology. Available at: <https://www.theguardian.com/technology/2019/jan/21/whatsapp-limits-message-forwarding-fight-fake-news>. Retrieved May 17, 2019.

20 COMPROVA. Jornalismo colaborativo contra a desinformação. Available at: <http://projetocomprova. com.br>. Retrieved May 22, 2019.
} 
justice works as a mediator. Thus, a candidate may file lawsuits alleging that the other has created disinformation or has offended his image. The judges have the power to suspend the display of the candidate's radio and television presentations or to order that a candidate gets the right to reply. Already concerning social media, the court lacks this power; that is, the mediation is done by the companies themselves, which respond before the court. There is no punishment for the candidate's benefit. At most, the exclusion of information will occur.

There were no surprises in who filed lawsuits. Of the total number of plaintiffs, the two leading candidates accounted for $70 \%$. Haddad accounted for $42 \%$ of that total. Facebook, Google, and Twitter appear in most of the actions, being defendants in 30,21 , and 13 suits, respectively:

\begin{tabular}{|c|c|c|c|}
\hline \multicolumn{4}{|c|}{ Table 1 - Lawsuits as plaintiff } \\
\hline Candidate or coalition & Lawsuits $\left(1^{\text {st }}\right.$ round) & Lawsuits $\left(2^{\text {nd }}\right.$ round $)$ & Total \\
\hline Haddad & 3 & 18 & 21 \\
\hline Bolsonaro & 2 & 12 & 14 \\
\hline
\end{tabular}

\begin{tabular}{|c|c|}
\hline \multicolumn{2}{|c|}{ Table 1- Lawsuits as defendant } \\
\hline Social Media Company & Lawsuits \\
\hline Facebook & 30 \\
\hline Google & 21 \\
\hline Twitter & 13 \\
\hline
\end{tabular}

It is interesting to note that 30 of the 35 suits brought by the two candidates were proposed in the second round of elections. This is an indicator of how disinformation-spreading became more frequent in the final phase of the electoral process. Alternatively, the issue became more worrisome in the closing stages of the campaign.

The authors cited WhatsApp in 4 lawsuits, all of which happened in the second round. In 3 lawsuits brought by Haddad, there were WhatsApp references only to say that disinformation-spreading was taking place while he called for concrete action on other social media. Bolsonaro cited WhatsApp in just 1 suit when he complained that Haddad's advertising was saying on radio and television that Bolsonaro was lying on WhatsApp. The lack of suits on WhatsApp shows that the candidates did not have enough attention for WhatsApp or did not see an electoral justice with the power to fight the disinformation on WhatsApp.

We know that unlike social media like Facebook and Twitter, WhatsApp is characterized by direct messages between users or groups without the mediation of the company. There is no choice of which messages and which users will be displayed. Also, 
there is the difficulty of identifying false messages since the messages are protected by encryption.

Despite the existence of objectionable decisions, there is no absurdity in the content of judicial decisions. There was an obvious concern with the non-transformation of the court into a censor board. For this, the judges expressed the intention to hold the space of debate and criticism as freely as possible.

The judges only took decisions favorable to requests for the exclusion of information when they were faced with information that was undoubtedly false. In some court decisions, although it faced messages that were damaging to the image of the candidates, the court chose not to exclude the content, stating that any falsity regarding the content of the video can be evaluated by the Internet users themselves, thereby prevailing the free circulation of ideas and their public confrontation, so as to safeguard the freedom of speech and thought of people. ${ }^{21}$ This way of deciding is consistent with legislation aimed at the least possible judicial interference in the debate.

It is important to note that the law sets very short deadlines for judges to decide in the electoral procedure. Thus, the depth of analysis is compromised by the need for an almost immediate response. In a general way, we can say that the court did a high-grade assignment deciding these lawsuits.

\subsection{Higher Electoral Court supervising the electoral process}

We can say that before the electoral period, the electoral judicial branch was aware that disinformation would be the main problem of the 2018 elections. Widespread disinformation already has impacted other electoral processes. Brazil itself had already seen campaigns of disinformation during previous elections, albeit of lesser impact. In 2017, the BBC reported that Brazil had armies of fake profiles on social media being used in the 2014 elections. However, regarding disinformation, the court failed in its role to oversee the 2018 electoral process to ensure its integrity.

This awareness was evident when, in December 2017, the TSE created a council to advise on fake news. There were 14 members, representing the court (4), electoral prosecutor (1), legislative branch (1), executive branch (6) and civil society (2). The act that created the council established that it would have the following attributions: 1 . to develop research and studies on electoral rules and the influence of the Internet on elections, especially the risk of fake news and the use of robots in the dissemination of information; 2. to give its opinion on the matters submitted to it by the Presidency of the TSE; 3. Propose actions and goals aimed to improve legal norms.

21 PERON, Isadora; MARTINS, Luisa. TSE nega novo pedido para retirar do ar fake news contra Haddad. Valor, October 10, 2018. Política. Available at: <https://www.valor.com.br/politica/5933037/tse-nega-novo-pedido-para-retirar-do-ar-fake-news-contra-haddad>. Retrieved May 20, 2019. 
According to information we received from the Court, there were ten Council meetings between December 2017 and October 2018. It is interesting to note from the data that although the first-round election campaign took place between August $16^{\text {th }}$ and October $7^{\text {th }}$, there was no meeting of the council during that period. The information we received shows that the Council had six meetings before this period and four meetings after it.

In the first round of voting, there was an avalanche of false news about the non-functioning electronic ballot boxes and voting fraud. These events caused concern in the court, which acted in the second round, denying this information and investigating its origins. The court created a website in the style of fact-checking institutions aimed explicitly at enlightening the electorate against disinformation campaigns. On this website, no information was posted about false news against candidates but only about the disinformation, misinformation, or mal-information that affected the image of the court and the voting process. Thirty-five messages were posted with explanations about rumors that distorted details about the functioning of the electoral system.

By the way, this website has an indicator that institutional action started very late: the fact that the first news piece on the online platform was published on October 11,2016 , when the first round of voting had passed.

There has been an approximation of the court with non-state fact-checking agencies. This path is praiseworthy. These agencies were already aware that WhatsApp was the great medium of sharing disinformation. Six days before the second round of elections, the court held a meeting with the agencies and companies responsible for social media. At that time, there was a general embarrassment when the WhatsApp representative named some agencies with whom she claimed WhatsApp was working, and they denied it instantaneously. The press reported on WhatsApp's reluctance to cooperate. The meeting was happening in Brasilia, and its representative was online from California; she had disconnected before hearing comments from other participants of the meeting.

The court established a dialogue with the companies responsible for social media. It is crucial to seek the commitment of these companies with the solution to the problem. These companies moderate social media and should then be charged to take organized action against these disinformation campaigns. ${ }^{22}$ However, we have no way of knowing what action was taken and what was accepted, since the court did not disclose any outcome of these discussions.

Cooperation between government and society is vital for solving the problem. If we wait for a solution exclusively from the government, we run the risk of legitimizing a disproportionate growth of public authorities, with risks to democracy. We agree with

22 KEYE, David. The Global Struggle to Govern the Internet. New York: Columbia Global Reports, 2019. 
Fergus Hanson, Sarah O'Connor, Mali Walker and Luke Courtois ${ }^{23}$ : "democracies have a natural aversion to government surveillance, a better answer than simply stepped-up government monitoring may be supporting non-profit, non-government initiatives and independent media".

We are, however, limited in the analysis of the court's performance because of the lack of transparency on the work of the body that advised it. It is a mistake to consider confidential the results of the commission's work that helped the Court. The challenge of maintaining the integrity of the electoral process requires that disinformation on the Internet be considered a central issue. For this, we need to understand that the struggle against disinformation processes are not just a matter of the authorities organizing the elections, but it is in the interest of all of us. Civil society could discuss and give back suggestions based on the experience of the institution. Moreover, not only is Brazilian society interested in such results. Other countries may also use this data when planning their public policies.

\section{WHAT LESSONS CAN WE DRAW FROM THE EXPERIENCE?}

Addressing the problem of disinformation campaigns needs to take its complexity into account. It is necessary to make the role that each agent plays in the dissemination of false information very clear. In a report for the Council of Europe, Claire Wardle and Hossein Derakhshan suggested seven questions to ask about an agent: 1) What type of actor are they? 2) How organized are they? 3) What are their motivations?; 4) Which audiences to they intend to reach? 5) Is the agent using automated technology? 6) Do they intend to mislead?7) Do they intend to harm?

Social bots are "automated or semi-automated accounts created to like, share, post or otherwise interact on the social networks".24 They are widely used in disinformation campaigns, and it is necessary to restrict them to reduce the impact of these campaigns on democracy. A study that observed 14 million messages that spread across 400,000 articles during ten months in 2016 and 2017 concluded that "curbing social bots may be an effective strategy for mitigating the spread of online misinformation".25 This cited study demonstrated how social robots act to make articles with low-credibility

23 HANSON, Fergus et al. Hacking democracies: Cataloguing cyber-enabled attacks on elections. Barton: ASPI, 2019. Available at: <https://www.aspi.org.au/report/hacking-democracies>. Retrieved May 19, 2019.

24 ALEMANNO, Alberto et al. Disinformation and propaganda: Impact on the functioning of the Rule of Law in the EU and its Member States. Brussels: European Parliament, Policy Department for Citizens'Rights and Constitutional Affairs, 2019. Available at: <http://www.europarl.europa.eu/RegData/etudes/STUD/2019/608864/ IPOL_STU(2019)608864_EN.pdf>. Retrieved July 29, 2019.

25 SHAO, Chengcheng et al. The spread of low-credibility content by social bots. Nature communications, vol. 9 (1), 2018. Available at: <https://www.nature.com/articles/s41467-018-06930-7>. Retrieved July 19, 2019. 
content viral. They act shortly after the articles are published, and they mention influential users, trying to get them to share that content.

Although the problem of using bots is real, people are among the main disseminators of false information on the internet. Ordinary people do not do it just because of political prejudice; people do it because they are lazy to think, and because of the attraction that novelty produces. ${ }^{26}$ For this facet of the problem, digital literacy seems to be one of the most important paths.

However, agents with a clear purpose of causing damage need to be seen differently. The intended production and dissemination of false information to distort the electoral debate needs to be fought more vigorously. In this case, there is someone who aims to destroy the bases of democracy.

It is essential to identify when political parties and candidates are behind the actions and, consequently, punish them. It is necessary to prevent parties and candidates from promoting disinformation campaigns. Political parties running in elections must take care of the integrity of this process. Acceptance of this duty should be seen as a precondition for participating in the elections.

The regulation of the electoral process will define the behavior of the actors participating in the dispute. Afterall, "institutions define the actions that particular actors can adopt, they provide incentives associated with each course of action, and constraints to the possible outcomes."27

This debate about what to do against the political parties that deliberately attack democracy will eventually find the so-called dilemma of militant democracy. Despite all the contests that exist to this concept, it is the base of the prohibition of political parties in Germany. There, the political party can be extinguished by the decision of the Federal Constitutional Court that considers its action contrary to the constitution. However, it is not a broad power for the court. For this, the political party must "take an actively belligerent, aggressive stance vis-à-vis the free democratic basic order and must seek to abolish it". ${ }^{28}$ Mark Tushnet ${ }^{29}$ argues that "there may be many paradoxes of free expression, or at least real tensions within the domain of free expression, but the

\footnotetext{
26 PENNYCOOK, Gordon; RAND, David G Lazy, not biased: Susceptibility to partisan fake news is better explained by lack of reasoning than by motivated reasoning. Cognition, [s.l.], vol. 188, p. 39-50, July 2019. Available at: <https://www.sciencedirect.com/science/article/pii/S001002771830163X>. Retrieved August 12, 2019.

27 PRZEWORSKI, Adam. Crises of democracy. Cambridge: Cambridge University Press, 2019.

28 BUNDESVERFASSUNGSGERICHT. Proceedings For the Prohibition of Political Parties. Available at: $<$ https://www.bundesverfassungsgericht.de/EN/Verfahren/Wichtige-Verfahrensarten/Parteiverbotsverfahren/ parteiverbotsverfahren_node.html>. Retrieved July 19, 2019.

29 TUSHNET, Mark. Advanced Introduction to Freedom of Expression. Elgar Advanced Introductions. Cheltenham, UK: Edward Elgar, 2014.
} 
paradox of militant democracy may be the one requiring the most urgent attention today."

Foreign organizations, in particular governments, are agents whose action in the political debate needs to be repressed. The national deliberative process must be sufficiently protected to represent the expression of the will of the members of the national community as much as possible. However, the possibility of protecting the national public space was strongly impacted by the Internet. The interconnectivity of the web allows easy access to information originating from the whole world, which means a door open to foreign interference. There is much evidence of Russia's orchestrated actions in recent electoral or referendum processes worldwide, such as the US elections ${ }^{30}$ and the Brexit referendum, ${ }^{31}$ both in 2016. Although there is no evidence that there was an influence of foreign governments on disinformation campaigns in Brazil, the vulnerability of the general electoral process is concerning.

\section{CONCLUSIONS}

How do we act in a situation in which we find active risks both in the omission and in the intervention? The debate about the size of the threat that disinformation and disinformation in electoral processes represent still seems inconclusive. We cannot overstate the display and justify the creation of unnecessary controls. On the other hand, we cannot underestimate the threats and remain inert. An evaluation error can be fatal: Actions under the pretext of protecting democracy can pose real risks, and the omission can fuel threats.

The 2018 Brazilian elections showed that it is necessary to have more active surveillance of the electoral process. In particular, should the authorities responsible for the soundness of the process prune these practices by candidates, parties, and people directly linked to them? It is not possible to consider the exposure of clearly false information about candidates "regular use of criticism." Nevertheless, the surveillance should respect personal data protection and other individual rights. It is recommended to work with civil society organizations and traditional media companies that could alert authorities when they face campaigns that seem professional.

Amid an election marked by disinformation, the court's primary concern in the 2018 elections was with information that weakened its image. The High Electoral Court

30 OFFICE OF THE DIRECTOR OF NATIONAL INTELLIGENCE. Background to ‘Assessing Russian Activities and Intentions in Recent US Elections': The Analytic Process and Cyber Incident Attribution. 2017. Available at: <https://assets.documentcloud.org/documents/3719492/Read-the-declassified-report-on-Russian.pdf>. Retrieved July 20, 2019.

31 FIELD, Matthew; WRIGHT, Mike. Russian trolls sent thousands of pro-Leave messages on day of Brexit referendum, Twitter data reveals. The Independent, October 17, 2018. Technology Intelligence. Available at: $<$ https://www.telegraph.co.uk/technology/2018/10/17/russian-iranian-twitter-trolls-sent-10-million-tweets-fake-news/>. Retrieved May 15, 2019. 
was right when it worked against disinformation on electronic voting because the reliability of the system was at stake. However, there were no reasons to accept the disinformation process as campaign strategies because campaigns against candidates and campaigns against electoral institutions were two sides of the same coin.

Democracy is not just about the electoral moment. In other words, the challenges to the construction or maintenance of democracy are continuous, not just when it comes to choosing leaders or consulting the people. However, this moment stands out because there are occasions where citizenship expresses itself and decides issues that will have repercussions for years in the life of society.

Institutions responsible for elections' integrity will need to go beyond their past experiences. If the regulation of the electoral process is not strong enough to discourage the inappropriate behavior of the agents, the problem tends to grow. Other candidates will see the illegal path as an efficient one and will not fear adopting bad practices.

Electoral authorities need to be prepared for new and more significant challenges such as the phenomenon that is called "deep fake." It will be hard to perceive the boundaries between truth and lies because audio and video production will be manipulated with perfect quality. This is a significant threat to electoral processes, since to deny it could be slow and few would be effective.

We need transparency. Authorities and social media companies should publish which ways they have adopted to avoid threats. It is not enough to say, "Trust me, the problem is solved!" Society does not merely want to change the opaque policies of companies by opaque policies of authorities. The lack of official reports on the TSE's performance weakens the fight against disinformation around the world. This silence goes in the opposite direction to what the OAS mission indicated when it said that TSE could "export the good practices developed during the Brazilian electoral process to other countries that face similar challenges in the context of the organization of their elections."

Changing the law to create new crimes does not seem to be the most appropriate way to fight disinformation. There is a range of options more compatible with preserving freedoms, such as digital literacy and fact-checking. However, these are limited tools. They act on individuals who are sharing malicious content out of ignorance, but who would not share it if they were aware of falsehood. However, additionally, it is necessary to have an investigative activity against the professional and malicious schemes of spreading information. This statement is especially true when it concerns a moment as crucial to a democratic state as the elections are. The existence of these digital mafias deliberately distorts the public debate that should characterize democracy. 


\section{REFERENCES}

ALEMANNO, Alberto et al. Disinformation and propaganda: Impact on the functioning of the Rule of Law in the EU and its Member States. Brussels: European Parliament, Policy Department for Citizens'Rights and Constitutional Affairs, 2019. Available at: <http://www.europarl.europa.eu/ RegData/etudes/STUD/2019/608864/IPOL_STU(2019)608864_EN.pdf>. Retrieved July 29, 2019.

BOOTH, Robert et al. Russia used hundreds of fake accounts to tweet about Brexit, data shows. The Guardian, November 14, 2017. World. Available at: <https://www.theguardian.com/world/2017/ nov/14/how-400-russia-run-fake-accounts-posted-bogus-brexit-tweets $>$. Retrieved Feb. 9, 2019.

BRAZIL. Código Eleitoral, Lei n. 4.737. Diário Oficial da União, Brasília, DF, July 15, 1965. Available at: <http://www.planalto.gov.br/ccivil_03/leis//4737.html>. Retrieved July 7, 2019.

BRAZIL. Lei n. 9.504. Diário Oficial da União, Brasília, DF, September 30 1997. Available at: <http:// www.planalto.gov.br/ccivil_03/LEIS/L9504.html>. Retrieved July 7, 2019.

BUNDESVERFASSUNGSGERICHT. Proceedings For the Prohibition of Political Parties. Available at: <https://www.bundesverfassungsgericht.de/EN/Verfahren/Wichtige-Verfahrensarten/Parteiverbotsverfahren/parteiverbotsverfahren_node.html>. Retrieved July 19, 2019.

COMPROVA. Jornalismo colaborativo contra a desinformação. Available at: <http://projetocomprova.com.br>. Retrieved May 22, 2019

ORGANIZATION OF AMERICAN STATES. Preliminary EOM report, Electoral Observation Mission of the Organization of American States, 2018. Available at: <http://www.oas.org/documents/eng/ press/Preliminary-Report-EOM-Brasil-2nd-round-ENG.pdf>. Retrieved July 17, 2019.

FIELD, Matthew; WRIGHT, Mike. Russian trolls sent thousands of pro-Leave messages on day of Brexit referendum, Twitter data reveals. The Independent, October 17, 2018. Technology Intelligence. Available at: <https://www.telegraph.co.uk/technology/2018/10/17/russian-iranian-twitter-trolls-sent-10-million-tweets-fake-news/>. Retrieved May 15, 2019.

FREEDOM HOUSE. Freedom in the World 2019. Available at: <https://freedomhouse.org/sites/ default/files/Feb2019_FH_FITW_2019_Report_ForWeb-compressed.pdf $>$. Retrieved July 19, 2019.

FREEDOM HOUSE. Freedom on the Net 2019. Available at: <https://www.freedomonthenet.org/ sites/default/files/2019-11/11042019_Report_FH_FOTN_2019_final_Public_Download.pdf >. Retrieved Sep. 20, 2019.

HANSON, Fergus et al. Hacking democracies: Cataloguing cyber-enabled attacks on elections. Barton: ASPI, 2019. Available at: <https://www.aspi.org.au/report/hacking-democracies $>$. Retrieved May 19, 2019.

HERN, Alex; SAFI, Michael. WhatsApp puts limit on message forwarding to fight fake news. The Guardian, January 21, 2019. Technology. Available at: <https://www.theguardian.com/ 
technology/2019/jan/21/whatsapp-limits-message-forwarding-fight-fake-news $>$. Retrieved May 17, 2019.

IDEIA BIG DATA. Elections and Fake News. October 2018. Available at: <https://avaazimages. avaaz.org/EN\%20IDEIA\%20-\%20Report\%20AVAAZ_v2\%203_EN\%20version_pdf\%20\%281\%29. pdf>. Retrieved May 17, 2019.

KALSNES, Bente. Fake News. Oxford Research Encyclopedia of Communication. September 2018, Available at: <https://oxfordre.com/communication/view/10.1093/acrefore/9780190228613.001.0001/acrefore-9780190228613-e-809>. Retrieved May 27, 2019.

KEYE, David. The Global Struggle to Govern the Internet. New York: Columbia Global Reports, 2019.

LAZER, David M. J et al. The Science of Fake News. Science, [s.l.]. v.359, issue 6380, p. 1094-1096, March 09, 2018. Available at: <http://science.sciencemag.org/content/359/6380/1094>. Retrieved July 17, 2019.

LONG, Clara. How False News Haunted the Brazilian Elections. Slate, October 30, 2018. Technology. Available at: <https://slate.com/technology/2018/10/brazil-election-fake-news-whatsappfacebook.html>. Retrieved May 21, 2019.

MELLO, Patricia Campos. Empresários bancam campanha contra o PT pelo WhatsApp. Folha de S. Paulo, October 18, 2018. Poder. Available at: <https://www1.folha.uol.com.br/poder/2018/10/ empresarios-bancam-campanha-contra-o-pt-pelo-whatsapp.shtml>. Retrieved July 25, 2019.

NORRIS, Pippa; GRÖMPING, Max. Electoral Integrity Worldwide. Sydney: The Electoral Integrity Project, 2019.

OFFICE OF THE DIRECTOR OF NATIONAL. Background to 'Assessing Russian Activities and Intentions in Recent US Elections': The Analytic Process and Cyber Incident Attribution. 2017. Available at: <https://assets.documentcloud.org/documents/3719492/Read-the-declassified-report-on-Russian.pdf>. Retrieved July 20, 2019.

ORTELLADO, Pablo; RIBEIRO, Márcio Moretto. Mapping Brazil's political polarization online. The conversation, August 3, 2018. Politics/Election '20. Available at: <https://theconversation.com/ mapping-brazils-political-polarization-online-96434>. Retrieved May 7, 2019.

PALMER, Ellis. Spain Catalonia: Did Russian 'fake news' stir things up?, BBC, November 18, 2017. Europe. Available at: <https://www.bbc.com/news/world-europe-41981539>. Retrieved May 17, 2019.

PENNYCOOK, Gordon; RAND, David G Lazy, not biased: Susceptibility to partisan fake news is better explained by lack of reasoning than by motivated reasoning. Cognition, [s.I.], vol. 188, p. 39-50, July 2019. Available at: <https://www.sciencedirect.com/science/article/pii/ S001002771830163X>. Retrieved August 12, 2019. 
PERON, Isadora; MARTINS, Luisa. TSE nega novo pedido para retirar do ar fake news contra Haddad. Valor, October 10, 2018. Política. Available at: <https://www.valor.com.br/politica/5933037/ tse-nega-novo-pedido-para-retirar-do-ar-fake-news-contra-haddad>. Retrieved May 20, 2019.

PRZEWORSKI, Adam. Crises of democracy. Cambridge: Cambridge University Press, 2019.

SABOIA, Fernanda. The Rise of WhatsApp in Brazil Is About More than Just Messaging. Harvard Business Review, April 15, 2016. Available at <https://hbr.org/2016/04/the-rise-of-whatsapp-in-brazil-is-about-more-than-just-messaging >. Retrieved May 7, 2019.

SHAO, Chengcheng et al. The spread of low-credibility content by social bots. Nature communications, vol. 9 (1), 2018. Available at: <https://www.nature.com/articles/s41467-018-06930-7>. Retrieved July 19, 2019.

TARDÁGUILA, Cristina; BENEVENUTO, Fabrício; ORTELLADO, Pablo. Fake News Is Poisoning Brazilian Politics. WhatsApp Can Stop It. The New York Times, October 17, 2018. Opinion. Available at: <https://www.nytimes.com/2018/10/17/opinion/brazil-election-fake-news-whatsapp.html>. Retrieved May 18, 2019.

TUSHNET, Mark. Advanced Introduction to Freedom of Expression. Elgar Advanced Introductions. Cheltenham, UK: Edward Elgar, 2014.

WARDLE, Claire; DERAKHSHAN, Hossein. Toward an interdisciplinary framework for research and policymaking. Strasbourg: Council of Europe, 2017. Available at: <https://rm.coe.int/information-disorder-toward-an-interdisciplinary-framework-for-researc/168076277c>. Retrieved July 3, 2019. 